\title{
Dyes and pigments used in foods: an integrative literature review
}

\author{
Corantes e pigmentos utilizados em alimentos: uma revisão integrativa da literatura \\ Colorantes y pigmentos utilizados en los alimentos: una revisión integrativa de la literatura
}

\begin{abstract}
The food colors are, in many countries, widely used to give food increased visual sensory quality, aiming, thus, the growth of the consumer market. Aware of this, the present work aimed to reevaluate the general properties of synthetic food dyes and natural pigments, the latter being generally used to replace the former. Then, the current analysis was based on the search for the strategy, selection of articles (with inclusion and exclusion criteria), eligibility, and data extraction. Thus, it was observed in studies that synthetic food dyes may cause several harmful effects to human health, among them, genetic damage and carcinogenicity. On the other hand, the use of natural pigments as an alternative to replace food dyes has been increasingly present in studies, presenting qualities that, previously, were not known, as is the case of anthocyanins, which have important physiological and ecological functions. It is also important to point out that the use of natural pigments goes beyond the limits of food, and are also found as sensitizers for solar cells, tissues, and medicines. Selected articles (47) leaded to a total of 72 distinct pieces of information, focused mainly on the biological activities and involving natural dyes and pigments. In short, the gradual replacement of dyes, currently used, still in large scale in some locations, by natural pigments, is already part of our present, allowing the creation of a future perspective with the production of processed foods without the damage that most of synthetic dyes produce to the human body.
\end{abstract}

Keywords: Dyes; Pigments; Foods; Review.

\section{Resumo}

Os corantes alimentares são, em muitos países, amplamente utilizados para conferir aos alimentos uma maior qualidade sensorial visual, visando, assim, o crescimento do mercado consumidor. Ciente disso, o presente trabalho teve como objetivo reavaliar as propriedades gerais de corantes alimentares sintéticos e pigmentos naturais, sendo estes geralmente utilizados em substituição aos primeiros. Em seguida, a análise atual baseou-se na busca da estratégia, seleção dos artigos (com critérios de inclusão e exclusão), elegibilidade e extração de dados. Assim, observou-se em estudos que os corantes alimentares sintéticos podem causar diversos efeitos nocivos à saúde humana, entre eles, danos genéticos e carcinogenicidade. Por outro lado, o uso de pigmentos naturais como alternativa para substituir os corantes alimentares tem estado cada vez mais presente nos estudos, apresentando qualidades que, anteriormente, não eram conhecidas, como é o caso das antocianinas, que têm importantes funções fisiológicas e ecológicas. É importante ressaltar também que o uso de pigmentos naturais vai além dos limites dos alimentos, sendo também encontrados como sensibilizantes para células solares, tecidos e medicamentos. Os artigos selecionados (47) levaram a um total de 72 informações distintas, 
voltadas principalmente para as atividades biológicas e envolvendo corantes e pigmentos naturais. Em suma, a substituição gradativa dos corantes, hoje utilizados, ainda em larga escala em alguns locais, por pigmentos naturais, já faz parte do nosso presente, permitindo a criação de uma perspectiva de futuro com a produção de alimentos industrializados sem os prejuízos que a maior parte das os corantes sintéticos produzem no corpo humano.

Palavras-chave: Corantes; Pigmentos; Alimentos; Revisão.

\section{Resumen}

Los colorantes alimentarios se utilizan ampliamente en muchos países para dar a los alimentos una mayor calidad sensorial visual, apuntando así al crecimiento del mercado de consumo. Consciente de ello, el presente trabajo tuvo como objetivo reevaluar las propiedades generales de los colorantes alimentarios sintéticos y los pigmentos naturales, que generalmente se utilizan para reemplazar a los primeros. Luego, el análisis actual se basó en la búsqueda de la estrategia, selección de artículos (con criterios de inclusión y exclusión), elegibilidad y extracción de datos. Por lo tanto, se observó en estudios que los colorantes alimentarios sintéticos pueden causar varios efectos nocivos en la salud humana, incluido el daño genético y la carcinogenicidad. Por otro lado, el uso de pigmentos naturales como alternativa para reemplazar colorantes alimentarios ha estado cada vez más presente en los estudios, presentando cualidades que antes no se conocían, como las antocianinas, que tienen importantes funciones fisiológicas y ecológicas. También es importante destacar que el uso de pigmentos naturales va más allá de los límites de los alimentos, encontrándose también como sensibilizadores de células solares, tejidos y medicamentos. Los artículos seleccionados (47) arrojaron un total de 72 piezas de información diferentes, principalmente centradas en actividades biológicas y que involucran tintes y pigmentos naturales. En definitiva, la paulatina sustitución de los tintes, utilizados hoy, todavía a gran escala en algunos lugares, por pigmentos naturales, ya forma parte de nuestro presente, permitiendo la creación de una perspectiva de futuro con la producción de alimentos industrializados sin las pérdidas. que la mayoría de los tintes sintéticos producen en el cuerpo humano.

Palabras clave: Tintes; Pigmentos; Alimentos; Revisión.

\section{Introduction}

Since ancient times, humans have sought to restore or enhance the colors of food. For instance, the ancient Egyptians were known to color their candy with natural plant extracts and wine as early as $1500 \mathrm{BC}$. In fact, until the middle of the 19th century, food coloration has been carried out with coloring matter supplied by nature, most frequently comprising spices and plant extracts but also animal derived pigments, such as squid ink, as well as brightly colored mineral pigments. The latter included often chronically harmful copper-, lead-, and tin-based pigments. In 1856, William H. Perkin discovered the first chemically synthesized dyestuff, namely, mauveine (syn. aniline purple and Perkin's mauve). Subsequently, a large number of artificial dyes were developed from aromatic starting compounds, such as aniline, From the 1950s to 1980s, numerous certified and approved artificial colorants were introduced and broadly used by the food industry. Commencing in the late 1980s and early 1990s, an increasing trend toward the use of "natural" ingredients led to the particular questioning of the use of artificial colorants in foods since there are evidences that they cause harmful to the consumers (Schweiggert, 2018; Abel, 2012).

Studies on health problems caused by synthetic food dyes are not as recent as one might think, for as early as the end of the last century, information concerning the carcinogenicity of caramel dye in ammonia process tested in F344 rats (Maekawa, et al., 1983). This work reported that a variety of tumors were triggered in all groups tested, counting the control group, leading to the conclusion that no dose-dependent effects were discovered on the incidence or time in which tumors could have formed in various organs and tissues, with the exception of the pituitary gland of males. In this, therefore, the side effects in males were, with respect to the administration of caramel solution, $4 \%$, thus showing a relatively higher rate than in the control. Finally, in the case of testing males, the highest incidence of pituitary tumors were in those who received the $4 \%$ caramel solution, a fact that can be explained by the variability of occurrence of spontaneous pituitary turnouts. The final conclusion was that under the conditions used in each test performed, the dye did not show carcinogenic effects in F344 rats (a statement that does not answer the question about its harm under other conditions). Based on the questions raised by such research, initiatives to improve the processing of synthetic dyes, more specifically, and their possible replacement, have been taken since relatively old publications and are perpetuated until the present day, with great advances obtained as promising discoveries were made. 
Oxidative stress is one of the most recurrent adverse effects found when studying food dyes in depth. This effect occurs due to the excessive amount of free radicals, generated by oxygen metabolization. When the amount of these is greater than the antioxidants, compounds that have the ability to moderate the effects caused by free radicals, the so-called oxidative stress occurs (Liberato, 2020). Therefore, it is necessary to include antioxidant compounds in the human diet, such as citrus fruits and berries. Free radicals are, basically, unstable compounds, possessing an unbound electron, aiming to realize it. Thus, the role of antioxidants becomes crucial, since it is well known that free radicals are very reactive compounds.

Therefore, among other harmful effects evaluated on synthetic dyes are the deleterious effects on the behavioral repertoire (Goldenring, et. al., 1980) and chromosomal breaks and mitotic aberrations caused by dyes such as fast green, indigo carmine, orange $\mathrm{G}$ and tartrazine, with methanyl yellow and fast green being the most influential (Roychoudhury \& Giri, 1989). Once harmful effects on human health have been detected, other studies aiming at the improvement and enhancement of techniques to remove food coloring qualifiers have been evaluated, such as the synthesis of modified microfiltration membrane prepared with graphene nano particles associated with tannic acid (Paixão, et al., 2019), and the adsorption of food coloring on chitosan films (Dotto, et al., 2015).

Based, therefore, on the ways that the Plant Kingdom uses to attract pollinators to itself, research has advanced to the field of natural pigments. Such compounds do not bring the devastating consequences that most synthetic dyes trigger to humans (the class of dyes that do not do so are the natural dyes, which will be addressed later). Therefore, the measures taken by the food industries, after the discovery of the harm caused by the dyes, were related to their replacement by natural pigments found in plants. In this way, among the most varied beneficial effects provided to man, one can find in these pigments the strong antioxidant capacity caused by anthocyanins, flavonoids and flavonols present in fruit extracts of Pronus mahaleb L. (Gerardi, et al., 2015); the preservation of neuron cell morphology and cell cycle even with dietary exposure to methylglyoxal (MGO) with the use of "dried tofu" (Lin, et al., 2018); the inhibition of acetylcholinesterase-induced aggregation of $\beta$-amyloid A $\beta$ 1-40, leading studies to new perspectives regarding the prevention of Alzheimer's disease (Panzella, Eidenberger \& Napolitano, 2018); and finally, the antioxidant capabilities present in seven pigments; among them, curcumin, have been proven by their ability to quench several free radicals, including 1,1-diphenyl-2-picrylhydrazyl (DPPH) and 2,2'-azinobis-3-ethylbenzothiazoline-6sulfonic acid (ABTS) (Zhang, et al., 2014).

It is interesting to note that the presence of natural pigments provides the human being with the most different benefits, which is also valid for other forms of life, as occurs with red rice, one of the main weeds of the rice fields cultivated in the United States. This is recognized by the dark coloration of the grains, demonstrating mutations that are responsible for the absence of proanthocyanidins (Gross, et al., 2010). However, the use of natural pigments goes beyond food issues, which is the peculiar case of the three compounds, obtained from cochineal (pure carminic acid: CA), papaya peel (raw papaya extract: PA) and Scenedesmus microalgae (chlorophyll: $\mathrm{Chl}$ ), being these tested as sensitizers in Titania solar cells, showing some efficiency in photoconversion (Orona-Navar, et al., 2020).

\section{Methodology}

\subsection{Type of Study}

The present study is a systematic review, whose main core is to reproduce, in a consistent manner, the search for solutions to scientific questions, such as finding and collecting available studies related to the main theme investigated, as well as reevaluating them and analyzing the data obtained. Thus, this systematic review was produced according to the PRISMA guidelines and parameters (http://www.prisma-statement.org/) (Moher, et al., (2009); Liberati, et al., (2009); Page, et al., (2021)), which followed the search strategy represented by Figure 1. 
Figura 1 - Flow diagram of the literature search process.
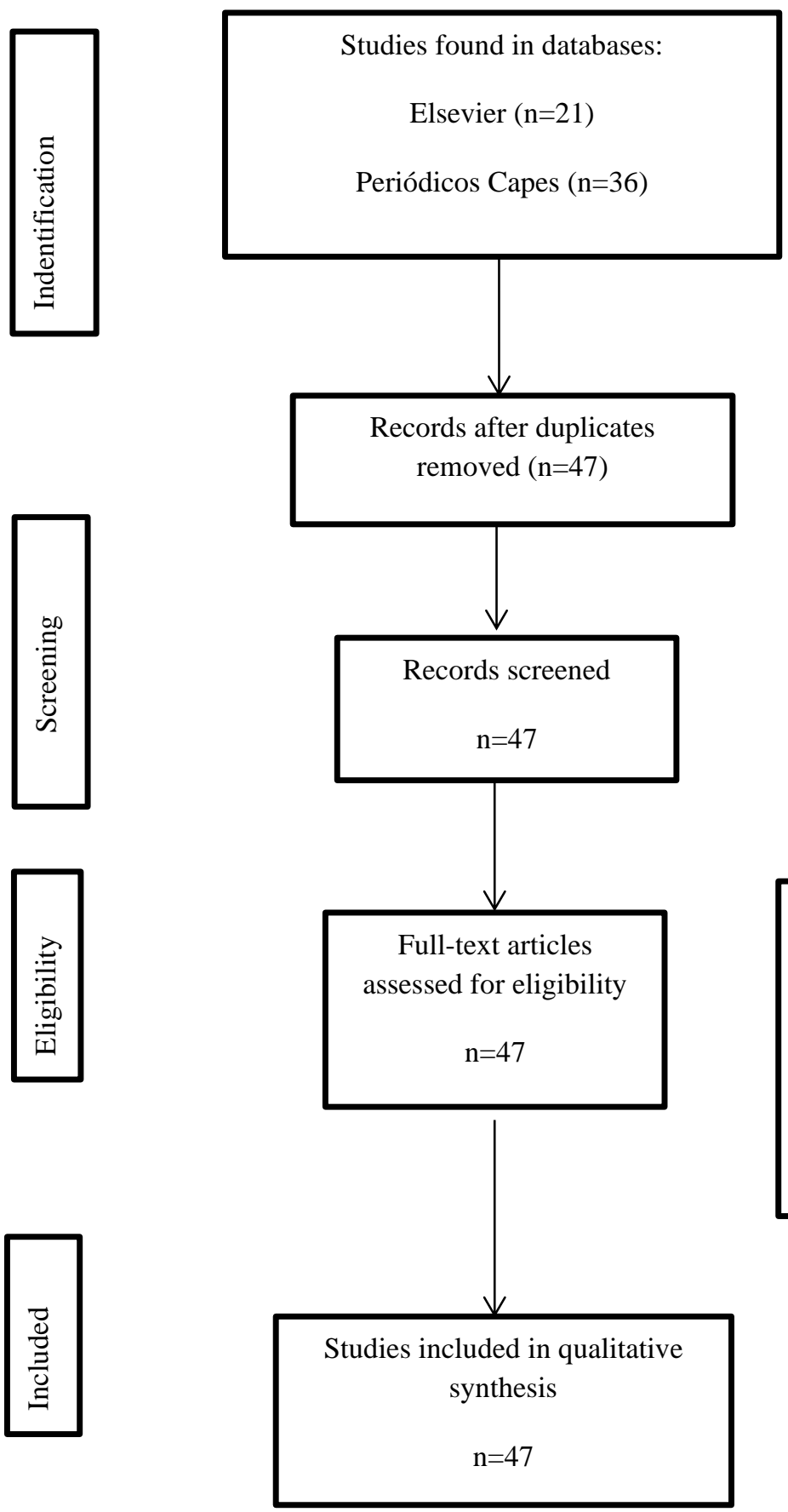

Records excluded $\mathrm{n}=10$

Full-text articles excluded, with reasons:

Due to countless evaluations before the first articles were selected, the inclusion and exclusion parameters fit the 47 separate articles.

Source: Authors

\subsection{Seek Strategy}

Regarding the sources used in the search for the main basis of this article, we used the portal Periódico Capes (www.periodicos.capes.gov.br) and Elsevier (www.elsevier.com) with dates ranging within the sample space from September 11, 1980 to January 1, 2020. The division performed by the research, therefore, used several groups of keywords, which can be highlighted: natural dyes, artificial, cancer, allergens, cytotoxic effects and antioxidant activity. A posteriori, the investigations were put into general (food dyes and natural pigments) and specific classes (including azo and caramel dyes, as well as the pigments anthocyanins and carotenoids) of the compounds analyzed here. In order to further and more orderly relate the structure 
to be addressed and the potentials arising from the various classes of dyes, assessments of potentials from standards such as Study Design and Data Collection Methods were used, following the PRISMA parameter.

\subsection{Article Selection}

\subsubsection{Inclusion Criterion}

The current review used articles evaluated mainly in vivo and in vitro, where ethical parameters were pre-established. Therefore, the purpose of this review is to elucidate the existing correlations between the use of food dyes and their cytotoxic and carcinogenic effects, for example, leading then to the comparison and suggestion of their replacement by natural pigments. Such compounds, in turn, have their origins purely from what does not correlate with nature. Attached to each of these essential characteristics for the specific study, the biological activities of the natural pigments were also taken into consideration for the selection of the articles present in the literature.

\subsubsection{Exclusion Criteria}

Review articles and repeated articles were necessarily excluded from the list of papers separated and put under evaluation for the writing of the present study. However, although this was the main criterion, other issues were also taken into consideration, such as research that used a relevant number of subjects and randomized studies (mostly withdrawn).

\subsection{Eligibility}

The guidelines followed for the elaboration of this article were assured in some phases, three specifically. The first, used as the stage of article selection, was based on ensuring that the titles of the due works were in agreement with the keywords used in the search for such writings. Then, with the selected studies catalogued, the strategy was formulated of observing, in a stricter manner, the articles in their entirety and in detail, in order to exclude supposed evaluations that broke away from the previously mentioned pre-established parameters. Thus, in the last procedure discussed, details following the PRISMA standard were performed. First, the "Component Classification" table was used, which is essential for a more detailed cataloging of the works themselves. In this, secondary divisions were performed, ranging from item (a) to (h), i.e., in richness of detail the subclassifications were Bias Selection, Study Design, Confounders, Blinding, Data Collection Methods, Withdrawals and Dropouts, Intervention Integrity, and Analysis. However, with regard to Withdrawals and Crashes and Intervention Integrity, there were questions that were not applicable to the design of this study. Finally, regarding specifically the questions addressed in each topic, six emerged as "not applicable" for the subsequent analysis of most of the papers analyzed in the literature, these being: percentage of selected subjects who agreed to participate in a given research, randomized studies, percentage of relevant confounding factors that were controlled, dropouts reported in quantitative form, percentage of participants who received the allocated intervention, and intentional intervention of subjects that may influence the results. It is worth noting that such responses are variable throughout the analyses discussed, since the studies themselves are carried out in different ways.

\subsection{Data Extraction}

In the step following the evaluation process of the studies covered in this paper, the year of publication (subcategories: first period, 1980-1981; second period, 1982-1983; third period, 1984-1985; fifth period, 1986-1987; sixth period, 1988-1989; seventh period, 1990-1991; eighth period, 1992-1993; ninth period, 1994-1995; tenth period, 1996-1996; eleventh period, 19971998; twelfth period, 1999-2000; thirteenth period, 2001-2002; fourteenth period, 2003-2004; fifteenth period, 2005-2006; sixteenth period, 2007-2008; seventeenth period, 2009-2010; eighteenth period, 2011-2012; nineteenth period, 2013-2014; twentieth period, 2015-2016; twenty-first period, 2017-2018; twelfth period, 2019-2020, twentieth period, 2020-current), 
scientific names of the natural dyes and pigments, country where the study was conducted, type of pathology triggered, specific treatment, side effects, alternative proposals, study design, control, and therapeutic effect were queries investigated and tabulated by the current study.

\subsection{Studies Included}

Following the PRISMA parameter, its diagram demonstrates the article selection flow (figure 1). The database search necessarily provided 47 articles (11 from Elsevier and 36 from the Capes Periodicals). It is important to mention the fact that, before being selected, these articles went through a series of selection criteria, which were reported and described in detail in previous topics. After this procedure, therefore, the articles were placed in two main groups: those that evaluated through in vitro tests and those that based their results on in vivo tests. Thus, it is notable that the former presented themselves as effectively more present than the latter. In general, however, most of the analyzed studies were classified according to PRISMA parameters (as well as questions) as "very likely" or "not very likely".

\subsection{Qualitative Analysis}

The largest number of articles reported and published before the observed literature was during the period 2014-2015, next to the period 2018-2019 (Table 1). It was noticed that antioxidant and antiradical capabilities were the most reported biological activities when it comes to the studies focused on natural pigments, with $11.11 \%$, as well as genotoxic effects were demonstrated for the dyes studied, obtaining the percentage of $6.94 \%$ (Table 2). However, it is interesting to highlight the fact that the values are based on the total of articles (47), taking into consideration that one of these may demonstrate joint activities and/or pathogenic effects (in the case of dyes currently used by the food and textile industries, mainly), and not just one characteristic alone. On the other hand, not only promising or harmful effects were found present in the literature, but, yes, extraction and identification of compounds were represented as relevant themes addressed in a significant amount, more precisely $6.94 \%$ (Table 2). Regarding the number of countries present, the total amount evaluated was 21 nations, adding the countries of each researcher found in the articles. 
Research, Society and Development, v. 10, n. 10, e316101018925, 2021

(CC BY 4.0) | ISSN 2525-3409 | DOI: http://dx.doi.org/10.33448/rsd-v10i10.18925

Table 1 - Distribution of published studies from 1980 to 2020.

\begin{tabular}{|c|c|c|}
\hline Periods & $\begin{array}{l}\text { Absolute value } \\
\text { (n) }\end{array}$ & $\begin{array}{l}\text { Relative value } \\
(\%)\end{array}$ \\
\hline $1980-1981$ & 1 & 2.13 \\
\hline $1982-1983$ & 1 & 2.13 \\
\hline 1984-1985 & 0 & 0 \\
\hline 1986-1987 & 0 & 0 \\
\hline 1988-1989 & 1 & 2.13 \\
\hline $1990-1991$ & 0 & 0 \\
\hline $1992-1993$ & 0 & 0 \\
\hline 1994-1995 & 0 & 0 \\
\hline 1996-1997 & 0 & 0 \\
\hline 1998-1999 & 0 & 0 \\
\hline $2000-2001$ & 2 & 4.26 \\
\hline $2002-2003$ & 0 & 0 \\
\hline 2004-2005 & 4 & 8.51 \\
\hline $2006-2007$ & 2 & 4.26 \\
\hline $2008-2009$ & 0 & 0 \\
\hline $2010-2011$ & 2 & 4.26 \\
\hline $2012-2013$ & 7 & 14.89 \\
\hline 2014-2015 & 12 & 25.53 \\
\hline $2016-2017$ & 3 & 6.38 \\
\hline 2018-2019 & 10 & 21.30 \\
\hline 2020-atual & 2 & 4.26 \\
\hline TOTAL & 47 & 100 \\
\hline
\end{tabular}

Source: Authors. 
Table 2 - Distribution of the effects caused by the use of food dyes and natural pigments.

\begin{tabular}{|c|c|c|}
\hline Side Effects & $\begin{array}{l}\text { Absolute } \\
\text { Value (n) }\end{array}$ & $\begin{array}{l}\text { Relative } \\
\text { Value (\%) }\end{array}$ \\
\hline Interaction with human serum albumin & 1 & 1.39 \\
\hline Genetic damage and carcinogenicity & 3 & 4.17 \\
\hline Interaction with collagen fibers & 1 & 1.39 \\
\hline Influence on the cells of the root meristem & 1 & 1.39 \\
\hline Toxicity and genotoxic & 5 & 6.94 \\
\hline Oxidative stress & 4 & 5.56 \\
\hline Behavior & 3 & 4.17 \\
\hline Memory & 2 & 2.78 \\
\hline Depression & 1 & 1.39 \\
\hline Anxiety & 1 & 1.39 \\
\hline Antisocial behaviors & 1 & 1.39 \\
\hline Hyperactivity & 3 & 4.17 \\
\hline Learning & 1 & 1.39 \\
\hline Triggering lymphopenia & 1 & 1.39 \\
\hline Pure synthesis & 4 & 5.56 \\
\hline Antioxidant and anti-radical capacity & 8 & 11.11 \\
\hline Determination method & 2 & 2.78 \\
\hline Allergic reactions & 1 & 1.39 \\
\hline Effect on leukocytes & 1 & 1.39 \\
\hline Adsorption and removal & 4 & 5.56 \\
\hline Chromosomal effects & 1 & 1.39 \\
\hline Stability & 1 & 1.39 \\
\hline Content of phenolic and flavonoid compounds & 3 & 4.17 \\
\hline Extraction and identification & 5 & 6.94 \\
\hline Natural sifting platform & 1 & 1.39 \\
\hline Biosynthesis & 2 & 2.78 \\
\hline Production of phenolic and flavonoid compounds & 1 & 1.39 \\
\hline Vitamin $\mathrm{C}$ contente & 1 & 1.39 \\
\hline Proanthocyanidin contente & 2 & 2.78 \\
\hline Cell photoconversion & 1 & 1.39 \\
\hline Spontaneous reversal & 1 & 1.39 \\
\hline Damage to children's intelligence & 1 & 1.39 \\
\hline Attention déficit & 1 & 1.39 \\
\hline Anti-amyloid aggregating activity & 1 & 1.39 \\
\hline Alzheimer's disease prevention agente & 1 & 1.39 \\
\hline Diabetes & 1 & 1.39 \\
\hline TOTAL & 72 & 100 \\
\hline
\end{tabular}




\subsection{Assessment of Study Quality}

The ranking of each article within the six methodological criteria yielded and proposed by the EPHPP tool as well as the overall ranking bias are demonstrated in rich detail

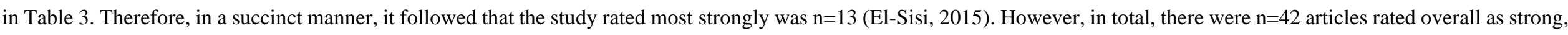
followed by $n=5$ rated as moderate, thus leaving $n=0$ for studies rated as weak.

Table 3 - Quality classification of selected articles.

\begin{tabular}{|c|c|c|c|c|c|c|c|}
\hline Study & Selection bias & Study design & Confounders & Blinding & $\begin{array}{l}\text { Data collection } \\
\text { methods }\end{array}$ & $\begin{array}{l}\text { Withdrawals and } \\
\text { drop-outs }\end{array}$ & Global rating \\
\hline Zhang \& Ma (2013) & Strong & Strong & Moderate & Moderate & Strong & Moderate & Strong \\
\hline Dwivedi \& Kumar (2015) & Strong & Strong & Moderate & Moderate & Strong & Moderate & Strong \\
\hline Vidal \& Mello (2005) & Strong & Strong & Moderate & Moderate & Strong & Moderate & Strong \\
\hline Santana, Sousa \& Peron (2015) & Strong & Strong & Strong & Moderate & Strong & Not Applicable & Strong \\
\hline Balta, et al., (2019) & Strong & Strong & Strong & Moderate & Strong & Moderate & Strong \\
\hline Başak, et al., (2014) & Strong & Strong & Moderate & Moderate & Strong & Moderate & Strong \\
\hline Başak, et al., (2016) & Strong & Strong & Moderate & Moderate & Strong & Moderate & Strong \\
\hline Doguc, et al., (2012) & Strong & Strong & Strong & Moderate & Strong & Strong & Strong \\
\hline El-Nabarawy, et al., (2015) & Strong & Strong & Strong & Moderate & Strong & Strong & Strong \\
\hline El-Sisi, et al., (2015) & Strong & Strong & Strong & Strong & Strong & Strong & Strong \\
\hline Ohtoyo, et al., (2016) & Strong & Strong & Strong & Moderate & Strong & Strong & Strong \\
\hline Maekawa, et al., (1983) & Strong & Strong & Strong & Moderate & Strong & Moderate & Strong \\
\hline
\end{tabular}


Siwińska-Stefańska, et al., (2012)

Mutsuga, et al., (2011)

Beutner, et al., (2001)

Mourtzinos, et al., (2018)

Richhariya \& Kumar (2018)

Abramsson-Zetterberg \& Ilbäck (2013)

Medeiros, et al., (2012)

Jaworska, et al., (2005)

Tripathy \& Nair (2012)

Ali \& Bashier (2006)

Gupta, et al., (2006)

Al-Degs, et al., (2012)

Paixão, et al., (2019)

Dotto, et al., (2015)

Goldenring, et al., (1980)

Roychoudhury \& Giri (1989)

Espinosa-Acosta, et al., (2018)

Cho, et al., (2016)

Kuskoski, et al., (2004)

Phommalath, et al., (2014)

Hamdi, et al., (2020)

Park, et al., (2018)

Srivastava \& Vankar, (2015)

Stoll, et al., (2018)

Dangles, et al., (2018)

Taheri, Nasab \& Movafeghi (2015)

\begin{tabular}{lll} 
Moderate & Strong & Moderate \\
Strong & Strong & Strong \\
Strong & Strong & Strong \\
Strong & Strong & Strong \\
Moderate & Moderate & Moderate \\
Strong & Strong & Moderate \\
Strong & Strong & Strong \\
Strong & Strong & Strong \\
Strong & Strong & Strong \\
Strong & Strong & Strong \\
Strong & Strong & Strong \\
Strong & Strong & Strong \\
Strong & Strong & Strong \\
Strong & Strong & Strong \\
Strong & Strong & Strong \\
Strong & Strong & Strong \\
Strong & Strong & Moderate \\
Strong & Strong & Strong \\
Strong & Strong & Strong \\
Strong & Strong & Strong \\
Strong & Strong & Strong \\
Strong & Strong & Strong \\
Mtrong & Strong & Strong \\
Strong & Strong & Strong \\
\hline
\end{tabular}

$$
\begin{aligned}
& \text { Strong } \\
& \text { Strong } \\
& \text { Strong } \\
& \text { Strong } \\
& \text { Strong } \\
& \text { Strong } \\
& \text { Strong } \\
& \text { Strong } \\
& \text { Strong } \\
& \text { Strong } \\
& \text { Strong } \\
& \text { Strong } \\
& \text { Strong } \\
& \text { Strong } \\
& \text { Strong } \\
& \text { Strong } \\
& \text { Strong } \\
& \text { Strong } \\
& \text { Strong } \\
& \text { Strong } \\
& \text { Strong } \\
& \text { Strong } \\
& \hline
\end{aligned}
$$

$\begin{array}{ll}\text { Not Applicable } & \text { Moderate } \\ \text { Not Applicable } & \text { Strong } \\ \text { Not Applicable } & \text { Strong } \\ \text { Strong } & \text { Strong } \\ \text { Moderate } & \text { Moderate } \\ \text { Strong } & \text { Strong } \\ \text { Not Applicable } & \text { Strong } \\ \text { Strong } & \text { Strong } \\ \text { Strong } & \text { Strong } \\ \text { Moderate } & \text { Strong } \\ \text { Moderate } & \text { Strong } \\ \text { Moderate } & \text { Strong } \\ \text { Moderate } & \text { Strong } \\ \text { Moderate } & \text { Strong } \\ \text { Strong } & \text { Strong } \\ \text { Moderate } & \text { Strong } \\ \text { Moderate } & \text { Strong } \\ \text { Moderate } & \text { Strong } \\ \text { Moderate } & \text { Strong } \\ \text { Moderate } & \text { Strong } \\ \text { Moderate } & \text { Strong } \\ \text { Moderate } & \text { Strong } \\ \text { Moderate } & \text { Strong } \\ \text { Moderate } & \text { Moderate } \\ \text { Moderate } & \text { Strong } \\ \text { Moderate } & \text { Strong } \\ \end{array}$


Research, Society and Development, v. 10, n. 10, e316101018925, 2021

(CC BY 4.0) | ISSN 2525-3409 | DOI: http://dx.doi.org/10.33448/rsd-v10i10.18925

\begin{tabular}{|c|c|c|c|c|c|c|c|}
\hline Bahorun, et al., (2004) & Strong & Strong & Strong & Moderate & Strong & Moderate & Strong \\
\hline Kandil, et al., (2000) & Strong & Strong & Strong & Moderate & Strong & Strong & Strong \\
\hline Xiao, et al., (2014) & Moderate & Strong & Strong & Moderate & Strong & Moderate & Moderate \\
\hline Orona-Navar, et al., (2020) & Moderate & Moderate & Weak & Moderate & Strong & Moderate & Moderate \\
\hline Gerardi, et al., (2015) & Strong & Strong & Moderate & Moderate & Strong & Moderate & Strong \\
\hline Gross, et al., (2010) & Strong & Strong & Strong & Moderate & Strong & Strong & Strong \\
\hline Lin, et al., (2018) & Strong & Strong & Strong & Moderate & Strong & Strong & Strong \\
\hline Panzella, Eidenberger \& Napolitano (2018) & Strong & Strong & Moderate & Moderate & Strong & Moderate & Strong \\
\hline Zhang, et al., (2014) & Strong & Strong & Strong & Moderate & Strong & Moderate & Strong \\
\hline
\end{tabular}

Source: Authors. 


\section{Results and Discussion}

The results presented a coherence in relation to the results obtained and to those expected in a period prior to the beginning of the evaluations. Therefore, it was noticed that, of the 47 articles cited, they presented 72 information based on scientific evidence, both of efficacy through natural pigments, and of damages caused by dyes found currently in use (often unrestricted) in the food industry. Among this amount reported, a better division analysis shows that some of the studies approached the theme in the form of a comparative, between food dyes and pigments, as is the case of tar (functioning as an alternative way to replace the dyes commonly used).

Another important point detected in the main theme established by this study is that the quantity of studies within the sample space from 1980 to the current period, classified and selected according to eligibility, are of considerable amount, which makes, increasingly, the subject of food dyes and the discovery of new natural pigments, as alternative coloring more relevant over the years. Thus, it is easy to see that, as the journals have been published and accepted by the scientific community, the annual number of publications has shown an increase, respecting the discrepancies, as it is thoroughly explained in table 1 . However, as it was put on the agenda earlier, the table does not follow a pattern of publications, but it is noteworthy that the most significant amounts are present in the most recent periods (2014-2015, with 12 published articles, and 2018-2019, with 11 published articles), which leads to the conclusion of the possibility that, in later years, this number tends to increase gradually. Last but not least, another briefly important issue to be pondered is the fact that the classification of articles according to table 3 does not present an overall evaluation in "weak" or "not applicable", but, in the sub-classifications, one weak in the "Confounders" bias and five not applicable in the "Withdrawals and Dropouts" class were found, reinforcing the condition treated in previous subtopics, which describe the points analyzed by means of the PRISMA standard in detail.

\subsection{Food Coloring:}

\subsubsection{Azo Groups (Class of Synthetic Organic Dyes)}

The food dye amaranth (trisodium (4E)-3-oxo-4-[(4-sulfonato-1-naphthyl)hydrazono]naphthalene-2,7-disulfonate), Figure 2, was investigated with respect to its interaction with human serum albumin (Zhang, et. al., 2013).The procedure was carried out by means of fluorescence, UV-vis absorption, circular dichroism (CD) and Fourier Transform Infrared (FT-IR) spectroscopy, generating a series of quite thought-provoking results regarding the binding of amaranth with albumin (HSA). Basically, such interaction was mainly driven by hydrophobic bonds and hydrogen bridges, which was understood through the negative value of enthalpy change and the positive value of entropy change, leading to increased hydrophobicity of the HSA surface. In addition to this, another result was achieved with the CD and FT-IR spectra, showing that amaranth binding induced conformational changes of human serum albumin. 
Figure 2 - Amaranth structure.

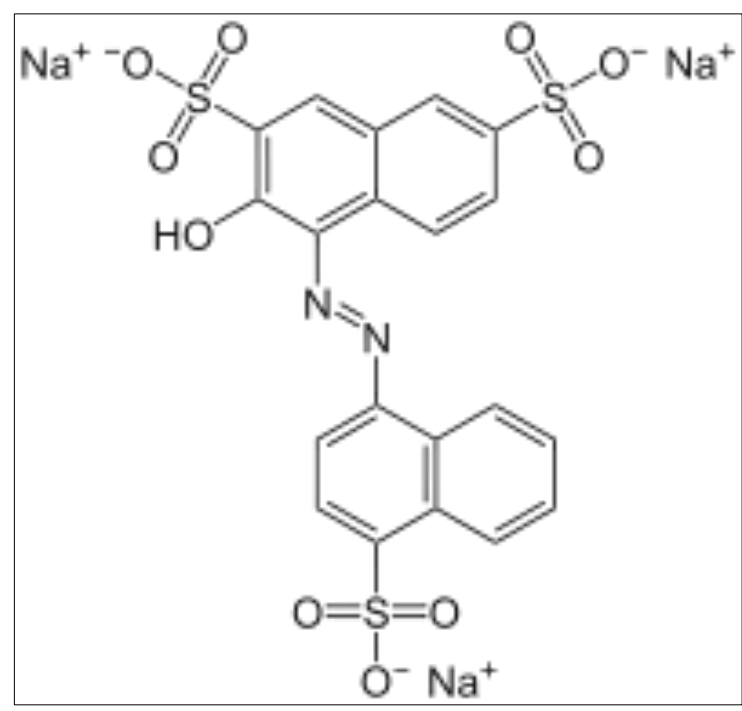

Source, et. al. (2013)

Sunset yellow (Disodium 6-hydroxy-5-[(4-sulfophenyl)azo]-2-naphthalenesulfonate), Figure 3, a dye included in the class of "azo compounds", was evaluated as a possible cause of genetic damage (Dwivedi, et. al., 2015) through interference in cell division in the root tip of Brassica Campestris L. Therefore, the results of the study were very clear and precise through mitotic analysis, demonstrating that the azo dye caused changes in the frequency of normal divisions, reducing them considerably and generating chromosomal aberrations at various stages of the cell cycle. Knowing this, the genotoxic and cytotoxic effect was proven, making it necessary to ban the use of such dye. However, it is important to emphasize that the study was conducted only in root plant cells, and there has not yet been a study with the application of the compound in human cells, more precisely in biota.

Figure 3 - Sunset yellow structure.

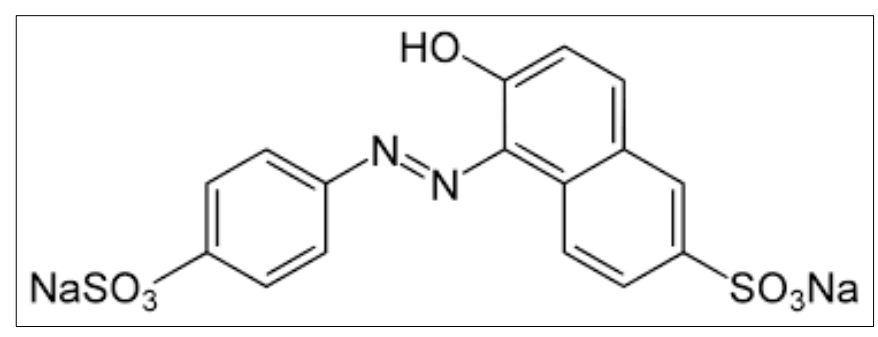

Source: Xu, et. al., (2012).

Some studies have been reported on a certain azo dye, Ponceau (trisodium (8Z)-7-oxo-8-[(4-sulfonatonaphthalen-1yl)hydrazinylidene]naphthalene-1,3-disulfonate), Figure 4. Initially, it was tested for its ability to complex with chicken tendon collagen fibers (Vidal \& Mello, 2005). This investigation was of paramount importance to determine the polarization properties and similarities with liquid crystals, thus forming structures with a higher level of orientation. Later, the evaluation performed on the ponceau dye was related to its toxicity by testing it in the cell cycle of meristematic cells of the roots of Allium Cepa L. (Santana, Sousa \& Peron, 2015). As a result, it was observed that, as occurred with the dye twilight yellow, the rate of cell division decreased significantly, thus leading to the conclusion that the dye ponceau is also classified as cytotoxic. 
Figure 4 - Ponceau structure.

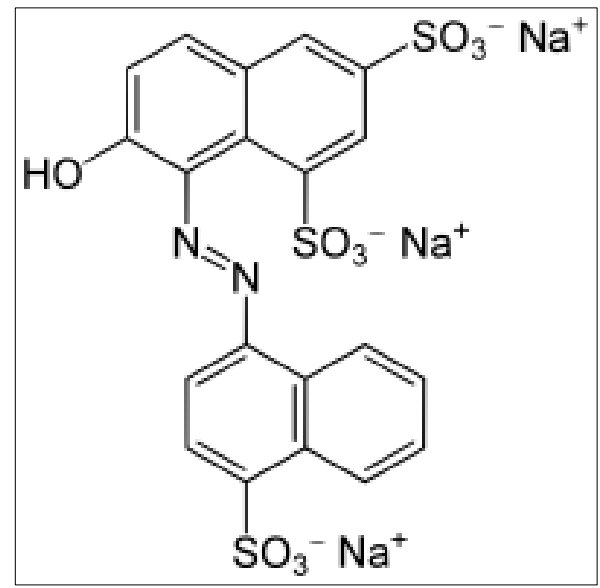

Source: Vidal e Mello, (2005).

The tartrazine dye (Trisodium (4E)-5-oxo- 1-(4-sulfonatophenyl)- 4-[(4-sulfonatophenyl)hydrazono]- 3pyrazolecarboxylate), Figure 5, was also a compound evaluated for its toxicity rate, through a test using 20 mature Wistar rats, being therefore performed in vivo (Balta, et. al., 2019). Certain experiment culminated in a result already somewhat expected: the addition of tartrazine in the diet of rats generated considerable changes in all hematological and biochemical parameters evaluated, thus, lesions in liver tissues and changes in blood parameters are proven, along with its toxicity. In addition to these issues, the study also addresses the ability of the tartrazine dye to cause changes in perception and behavior, causing agitation, confusion, rhinitis, and hyperactivity.

Figure 5 - Tartrazine structure.

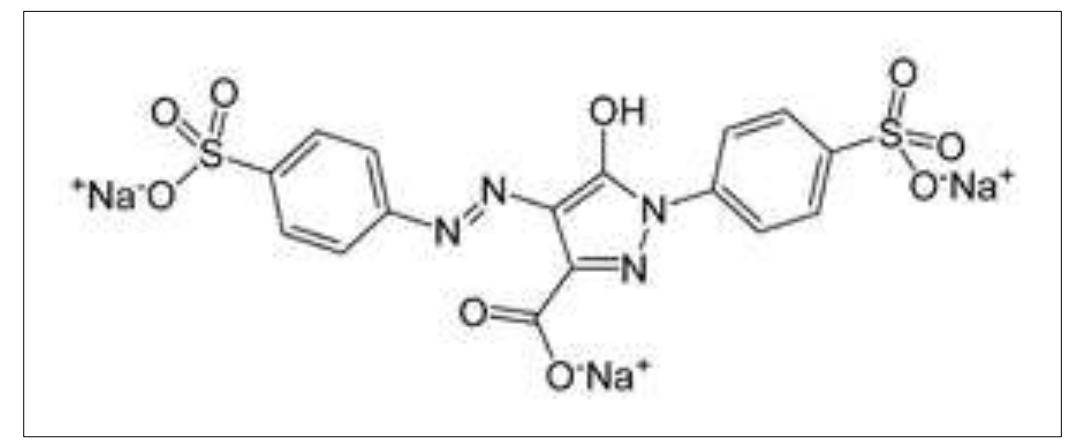

Source: Xu, et. al. (2012).

\subsubsection{Artificial Coloring}

Artificial dyes have been analyzed in many ways. This group of dyes is one of the most studied to date. It is worth noting that many of the compounds present in the azo groups are also catalogued as artificial colorants. The harmful effects of artificial colorings range from behavioral dysfunctions to even memory disorders. The first important point to address covers the possible carcinogenic effects arising from such dyes, those being evaluated via their effect on histomorphology and immunohistochemical expression in rats, with exposure performed by the mother (Basak, et. al., 2014). The study brought some essential observations regarding the role in the defense system generated by maternal exposure to AFCAs in the mucosa and, possibly, in the development of tumors and genetic instability, which occurred through the decrease in the calciform cell count. 
But still the evaluation of artificial dyes has taken on great proportions, investigating similarly the adverse effects on behavior and cognition, as well as the triggering of neoplastic and other inflammatory diseases in the skin. A certain study came about by identifying changes in the expression of GSTs, CYP1A1, and vascular endothelial growth factor (VEGF) in rat skin, which, similarly to the previously addressed study, the exposure was maternal (Basak, et. al., 2016). The results obtained assure us, therefore, that exposure provided by the mother apparently affects the expression of: CYP1A1, GSTs and VEGF in the skin, thus causing neoplastic and non-neoplastic skin diseases.

However, some other experiments performed in vivo deserve to be highlighted, such as the evaluation of the effects caused by artificial dyes on learning, directly linked to memory and behavior in children, aiming to obtain information about the possible side effects of artificial dyes. This investigation succeeded by feeding rats with acceptable daily intakes of widely used artificial dyes; among which, we can mention erythrosine, ponceau, tartrazine and amaranth; before and during pregnancy, thus aiming to achieve the necessary response to the certain impasses previously reported (Doguc, et. al., 2012). Therefore, as a result obtained, surprisingly, such dyes have no detrimental effects on operational memory, spatial and did not generate a depressive behavior to the pups. However, the use of the artificial dyes triggered significant effects on the locomotor system, i.e., increased some parameters in locomotor activity.

However, studies have advanced even further, reaching even the comparison between artificial dyes that have the property of generating depression, anxiety and antisocial behavior (El-Nabarawy, et. al., 2015). The evaluation was carried out according to the ingestion of tar in rats, later comparing its effects with the combined effect of each dose with curcumin (natural yellow dye). The main goal of the study, besides evaluating the behavior of the rats when fed with tar (possibly responsible for all the physical damage already mentioned) by means of the forced swimming, open field, and social interaction tests, was also to analyze the antidepressant effect of curcumin, a natural dye that will be better defined later. Thus, the final result was that, as expected, the artificial dye has the ability to develop depressive behavior, since prolonged immobilization was detected during the forced swim test. Thus, the anxiogenic and neurotransmitter inhibitory effects were proven, as the results of the open field tests, as well as the impairment of social interaction demonstrated deleterious effects caused by the dye in question. Finally, the promising effect of the natural dye curcumin was also proven, with this resolution being understood after this dye recovered the neurotransmitters previously inhibited by tar, and after having strong anxiolytic and antidepressant activities. It is worth mentioning that the study also analyzed another well-known and still used artificial coloring, which has also been mentioned in this work, tartrazine. This was evaluated as being a precursor to depression, anxiety, and antisocial behavior, just like tar.

In addition to these works presented so far on artificial dyes, one finds, last but not least, the comparative study of a certain artificial dye, more specifically the artificial yellow dye tar, with a natural dye also previously reported in this study, curcumin (El-Sisi, et. al., 2015). As can be seen, this evaluation is somewhat similar to the previous one cited in this paper, with some differences: the aim of this study was to evaluate hyperactivity, learning and memory disorders in weanling rats. For this, it was necessary to characterize the biochemical and behavioral parameters in the individuals participating in the experiment. As a result, obtained by this study, it was proven that the tar is the depletion in learning and memory in recently weaned rats, and that curcumin, again quite promising, proved to be an effective antioxidant and anti-inflammatory.

\subsubsection{Caramel Dye (Ammonia Process)}

This class of dyes, somewhat restricted, also accommodates a high amount of damage when they are inserted into human food. The first point to note is the correlation of the compound 2-acetyl-4-(tetrahydroxybutyl)-imidazole, known as THI (caramel color III), with excessive decrease in lymphocytes, a disease known as lymphopenia (Ohtoyo, et. al., 2016). A certain study developed a mechanism of action (evaluated in vitro and in vivo in rats) using THI derivatives and thus brought us the elucidation 
of the doubt that had about such harm generated by the compound, via inhibition of S1PL. Besides this, another study was identified with the main purpose of evaluating the effects of caramel dye with ammonia process, this one related to carcinogenicity, tested in rats (Maekawa, et. al., 1983). As a result, the analysis showed that the caramel dye was not carcinogenic, since spontaneous pituitary turnouts were present.

\subsubsection{The Use of Inorganic Oxides}

Since the harmful effects of food colorants are known, it is therefore necessary to understand how they are characterized. This, in turn, is accomplished with compounds acquired via adsorption on inorganic oxides. The first study, in particular, used inorganic oxides based on anatase titanium dioxide (Siwińska-Stefańska, et. al., 2012). It brought the prerogative of pointing out that the yellow dye was best adsorbed on the surface of titanium dioxide $\left(\mathrm{TiO}_{2}\right)$, and that the pigments derived from this dye presented quite stable. Besides this important observation, another was well put is that the surface of titanium dioxide and silicon dioxide $\left(\mathrm{SiO}_{2}\right)$ showed better elution capacity than the surface composed only of $\mathrm{TiO}_{2}$. Another analysis, regarding the detection of $\mathrm{SiO}_{2}$ and other oxides on $\mathrm{TiO}_{2}$ and certain silicates used in food additives, the dyes, has been identified (Mutsuga, et. al., 2011). This study used energy dispersive $x$-ray fluorescence (EDX) spectroscopy to evaluate the compounds in question, bringing a promising result for the separation of impurities in titanium dioxide and certain silicates.

\subsubsection{Synthetic Organic Dye}

This class of dye brought, until a recent period, a number of doubts about their genotoxic and carcinogenic capabilities, because some publications have related such harm to these compounds. Therefore, a study evaluated such possible properties of the dye Allura Red AC (E129), a dye that is also present in the azo groups, thus bringing elucidation to the doubt existing until then (Abramsson-Zetterberg, et. al., 2013). However, contrary to the studies that existed until then, Allura Red AC was not shown to be genotoxic, and consequently carcinogenic, in mice. Such a conclusion was drawn due to the absence of differences in cell proliferation (\%PCE) and micronucleated polychromatic erythrocyte frequency (fMNPCE) tests.

However, methods for the determination of synthetic dyes have also been developed, which are very common in food products: tartrazine, sunset yellow and brilliant blue (Medeiros, et. al., 2012). Since the methodology of the study was to evaluate the process performed simultaneously, it was developed in two pairs: tartrazine and sunset yellow, or brilliant blue and sunset yellow; with the final result obtained being the success of the voltammetric method of determination, resembling those obtained by means of High Performance Liquid Chromatography (HPLC). However, this was not the only study performed with the proposal of separation and determination. Another test was performed using micellar electrokinetic capillary chromatography, using 15 synthetic food dyes (Jaworska, et. al., 2005), and its results were also very promising. All dyes were separated in 20 minutes by means of a borate-fused silica capillary and had a very good acceptance and validation.

Finally, it is important to note that there are also the so-called mixed dyes, which are nothing more than dyes formed by the junction of natural and synthetic. These compounds have also been synthesized and characterized, thus demonstrating the possible emergence of a new subclass of dyes. Accordingly, the study used hibiscus sabdariffa and eosin $\mathrm{Y}$ for the synthesis of the mixed dye, subsequently employing it in the manufacture of solar cells that are sensitized with dyes (Richhariya \& Kumar, 2018). As a result obtained and of great importance for the analysis of the mixed dyes, was that the presence of the synthetic dye improved the efficiency of the natural dye, since an efficient light absorption was reported.

\subsubsection{Triphenylmethane}

The class of triphenylmethane dyes, Figure 6, thus recognized due to its molecular structure consisting of three phenyl groups, has basically two compounds widely used in both the food and pharmaceutical industries. These are the patent blue vital 
dye (PVB) and the fast green dye. The former is reported to be used in perioperative indications and can cause highly fatal allergic reactions. Knowing this, therefore, this study evaluated the blue dye in order to analyze its possible harm cited above (Tripathy \& Nair, 2012). Therefore, the result obtained was in line with what was expected, since of the 1.247 patients evaluated, 11 presented adverse reactions, a percentage of approximately $0.88 \% ; 6$ showed grade I, i.e., symptoms such as urticaria or generalized rash; 4 developed grade II, which encompasses symptoms such as hypotension and bronchospasm; and, finally, 1 patient presented grade III, requiring hypotension and prolonged vasopressor support. Such responses from each organism were due to the fact that the patent blue vital dye is actually harmful to humans, although no deaths were recorded, thus demonstrating the potential to trigger adverse reactions.

Figure 6 - Triphenylmethane structure.

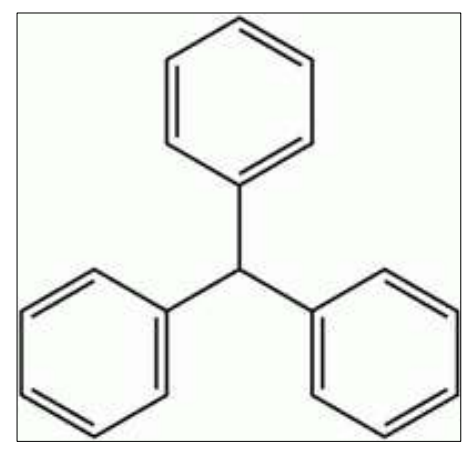

Fonte: Bettin, et. al., (2019).

The other dye that makes up the class of triphenylmethane dyes, and that, in addition to its use in cosmetics and pharmaceutical industries is also present as a food coloring, is the fast green. This, in turn, was analyzed for its possible effect on the leukocytes of male albino mice (Ali \& Bashier, 2006). This investigation, therefore, relied on five equal groups, since one of these worked as the control group, and the individuals were fed only with drinking water for 44 days. Therefore, the answer obtained through this experiment was that the fast green dye is an immunotoxic agent.

\subsubsection{Xanthene}

Xanthene, Figure 7, is a yellow organic molecule with heterocyclic chain, also widely used in organic synthesis and as a fungicide. Basically, the formation of this group of dyes is restricted to the dye erythrosine, also known as acid red 51, which is well known for its actions contrary to human health, including carcinogenicity. This dye is most often found in foods, medicines, cosmetics, and textiles. Thus, a mechanism to remove the erythrosine dye was investigated, using chicken feathers as adsorbents (Gupta, et. al., 2006). With this, the study was too efficient, due to issues such as the association with Freundlich and Langmuir isotherms, satisfying the two models used, being considered the adsorption process of endothermic nature and resulting in a mechanism of particle diffusion. However, another study also evaluated the adsorption capacity of the dye erythrosine, this time with the use of Pittsburg commercial activated carbon (Al-Degs, et. al., 2012). This important evaluation, through the equilibrium distribution, indicated high affinity of the dye for the activated carbon, being also an endothermic and spontaneous process at temperatures from $293 \mathrm{~K}$ to $313 \mathrm{~K}$, thus bringing the conclusion that the Pittsburg activated carbon works as an optimal component in the removal of erythrosine. It is worth mentioning that the experiment analyzed the variables based on PCA, being this responsible for correlating those with the $\mathrm{K}_{\mathrm{d}}$ (equilibrium) values. 
Figure 7 - Xanthene structure.

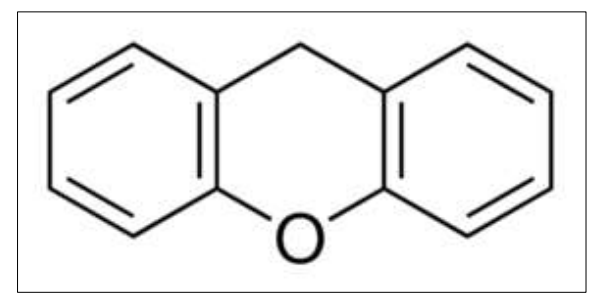

Source: Maia, et al, (2021).

\subsection{Natural Pigments}

These compounds, also known as natural organic dyes, have appeared in various studies as a healthy and promising alternative to replacing the use of food dyes, previously treated as food additives. It is worth noting that the use of dyes goes beyond food, covering also the pharmaceutical and textile industries. Some dyes, as already seen, are applied even in all these industrial fields at the same time, thus showing a certain versatility, but bringing with them serious factors detrimental to human health. Therefore, natural pigments are reported from their antioxidant properties, as is the case of the carotenoid molecule astaxanthin (Beutner, et. al., 2001), to even their economic and ecological potentials, such as, the use of onion (Allium Cepa) solid waste for the extraction of polyphenols (quercetin and derivatives) and the subsequent evaluation of their antirradicular response (Mourtzinos, et. al., 2018), showing promising results in both studies.

\subsubsection{Anthocyanins}

These compounds are basically derived from flavoyl salts and have innumerable benefits for the human body, Figure 8 . According to some literature, these compounds are classified as belonging to the flavonoid class, which will be better explained below (Kuskoski, et al., 2004). The first advantage of anthocyanins to be reported is their low toxicity. A study therefore evaluated alcoholic anthocyanin extracts taken from black carrot, aiming to increase their stability and determining whether microencapsulation with tetraethylorthosilicate is an interesting option to avoid anthocyanin degradation (Espinosa-Acosta, et. al., 2018). As a conclusion obtained, the antioxidant activity of the pigment present in the vegetable was evaluated by means of DPPH and CUPRAC radical scavenging, leading to the answer that anthocyanins is a grouping with optimal free radical fighting capacity. However, as the aim of the study was to evaluate microencapsulation, the research did not recommend the use of TEOS for black carrot extracts due to the results obtained in stability tests.

In view of the great importance of this class of natural pigments, other works emphasizing their synthesis were also found. This is the case of the study dealing with the MYB transition factor (PtrMYB119) from Populus Trichocarpa, which has the positive ability to regulate anthocyanin production when expressed under the control of the CaMV $35 \mathrm{~S}$ promoter in transgenic Arabidopsis (Ch, et. al., 2016). In addition to those mentioned so far, another study reiterated the fact that anthocyanin pigments are good antioxidant agents, this time by scavenging the ABTS-+ radical formed by reacting 2,2'azinobis-(3-ethylbenzothiazolin 6-sulfonic acid) with potassium persulfate for 16 hours at room temperature (Kuskoski, et. al., 2004). Thus, the study evaluated the antioxidant capacity of five anthocyanins: delphinidin, cyanidin, peonidin, pelargonidin and malvidin, thus highlighting that anthocyanins have strong antioxidant properties, equivalent to Trolox, with the exception of delphinidin and cyanidin 3glycoside, which demonstrated capacities twice as high as Trolox.

Finally, a study concerning the revelation of genetic variation in the content of phenolic compounds (PCCs), such as anthocyanins and proanthocyanidins (class of natural pigments that will be analyzed later), from seed teguments in 227 black soybeans was also evaluated (PHOMMALATH et. al., 2014). Certain research also brought another proof of the important antioxidant role of anthocyanins, via radical scavenging. Consequently, the final result obtained was that the development of 
black soybeans with the purpose of obtaining phenolic compounds activity is of paramount importance for the industry, especially food industry.

Figure 8 - Basic chemical structure of anthocyanins.

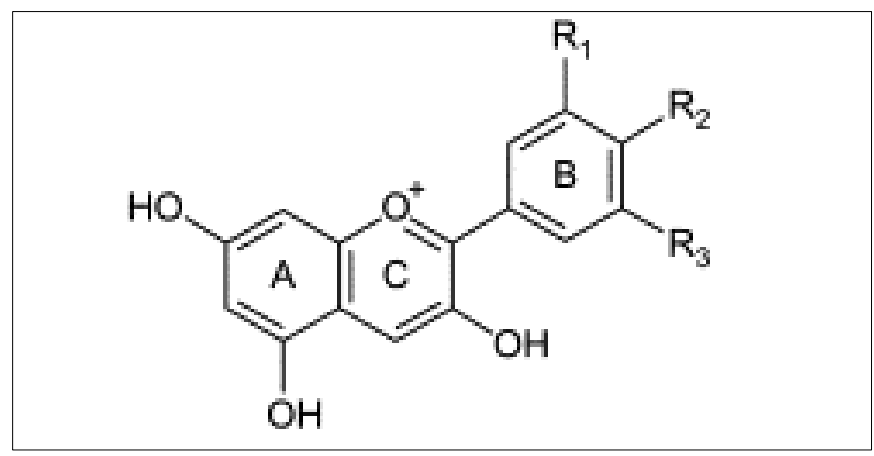

Source: Bueno, et al (2021).

\subsubsection{Carotenoids}

This group of natural dyes known for its chemically heterogeneous structure also has several advantages for humans. This is, among many reasons, because of its various bioactivities, being employed, daily, in various fields (Hamdi, et. al., 2020). Knowing these issues that are essential beforehand for the understanding of the importance of replacing food dyes, currently used, by natural pigments, it was verified a promising extraction process of carotenoids from the shell of the blue crab, being subsequently identified by means of the HR-ESI-MS technique (Hamdi, et. al., 2020). Therefore, the compounds identified in this study can be widely used in both food and pharmaceutical industries.

One of the main properties that these pigments possess is their antioxidant potential, tested in the study regarding the content of natural organic dye present in Arthrospira Platensis, an available source of spirulina, with the subsequent evaluation of the antioxidant capacity provided by the carotenoid (Park, et. al., 2018), exhibiting positive significance. However, due to the great demand for eco-friendly products and dyes that are not toxic, such as those already used by the industry, other studies have been evaluated, which aimed to obtain new carotenoid-rich sources. Among these, a work performed with Red Canna flowers (Srivastava \& Vankar, 2015) was reported, which aimed at the ultrasonic extraction of the natural carotenoid dye, thus demonstrating a considerable improvement in the extraction procedure, mainly regarding the ease of the process due to the ultrasound waves. It is worth noting that this method of separating the compounds also has two important advantages: it is ecologically and economically feasible. Finally, this same work presented the antioxidant activity of the leaf extract by the elimination of DPPH (2,2-diphenyl-1-picrylhydrazyl), being identified later by electron paramagnetic resonance (EPR) study. As a result of the antioxidant potential, the flowers proved to be good free radical fighters.

With this, other studies evaluating the replacement of synthetic dyes by natural pigments were also found. However, the use of natural compounds in place of synthesized ones goes beyond food, reaching the packaging itself. As an example of this, research based on the incorporation of carotenoid extracts (bixin, lycopene, and $\beta$-carotene (Figure 9) into poly (lactic acid) films was observed, thereby reducing oxygen permeability and showing a lubricating effect, with elasticity being increased in the films by up to $50 \%$ (Stoll, et. al., 2018). Soon, of the identified carotenoids, bixin was the most stable in terms of brightness and darkness. It is interesting to note that the exchange of synthetic for natural dyes in polymeric materials also brings with it another positive consequence, which is that of ecological preservation. 
Figure 9 - $\beta$-carotene structure.

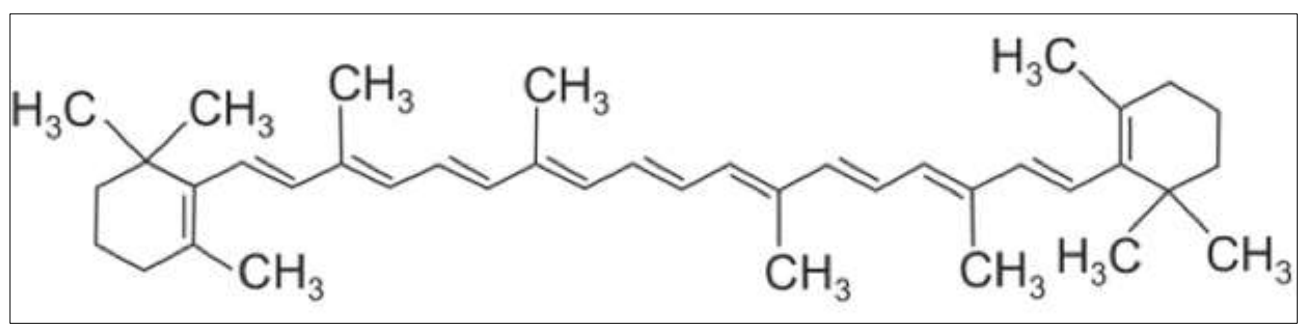

Source: Stoll, et. al. (2018).

The last and not least evaluated study on carotenoids concerns their ionization energy (EI) and for their ability to inhibit the induced peroxidation of linoleic acid in slightly acidic heme iron micelles (Dangles, et. al., 2018). Such research had the main objective of measuring the natural dye's ability to combat oxidative stress in the gastric compartment, using 11 carotenes and 14 xanthophylls (subclasses belonging to carotenoids). Thus, the result obtained by the study considered that the structure of the carotenoids influenced the calculations of EI and other specific parameters investigated. Regarding the antioxidant activity, it was directly related to the electron-donating capacity of carotenes, unlike xanthophylls, in which the ionization energy is not related to the length of the polyene chain due to the electronic effects of the atoms. However, other facts are determinant in classifying xanthophylls as possibly having viable promising performance, one of these being the radical scavenging mechanisms.

\subsubsection{Flavonoids}

According to some studies, anthocyanins (reported earlier) are part of the flavonoid group, as well as proanthocyanidins, which will also be treated in this topic. Among their numerous benefits, flavonoids stand out for having antioxidant and antiinflammatory activities and for helping in the treatment of other diseases, such as the human immunodeficiency virus (HIV). It is interesting to ponder that flavonoids do not prevent acquired immunodeficiency disease, but help in its treatment through the inhibitory action against the protease enzyme of the virus (Xu, et. al., 2000). Therefore, aware of these various characteristics brought by the group of natural flavonoid pigments, researches have aimed to reach new sources of production and obtaining these compounds. As is the case of the study that used the beneficial properties of Ziziphora Persica; among them, medicinal properties, for the production of phenolic and flavonoid compounds in cultivated nodal segments (Taheri, Nasab \& Movafeghi, 2015). As a result, it was investigated that the MS (Murashige and Skoog) medium with lower concentration was found to be the most suitable for the production of phenolic compounds and flavonoids.

However, other research has also been evaluated as producing phenolic pigments and flavonoids and further quantifying the total content of these, along with proanthocyanidin, vitamin $\mathrm{C}$ and antioxidant activity. Thus, an experiment based on the extraction and analysis of the total content of such compounds from ten Mauritian vegetables: broccoli, cauliflower, white cabbage, lettuce, Chinese cabbage, Artemisia, carrot, onion, tomato, and chili pepper (Bahorun, et. al., 2004), was investigated and catalogued as being of utmost importance, since it deals with several vegetables that make up the human diet. The correlation of these foods with the compounds represented here was relatively significant, with the exception of proanthocyanidin, which was found to be at very low levels in some vegetables. The vitamin C contents were quite oscillating, but with similarly considerable values. The antioxidant capacity measured was directly related to the amounts of total phenols and flavonoids calculated. In summary, the vegetables from Mauritius presented themselves as an indispensable source of phenolic compounds with antioxidant properties, since the quercetin derivatives stood out in this respect. 
Therefore, going more specifically into proanthocyanidins, a subclass of flavonoids, they are also highly evaluated for their properties, among which can be mentioned: antioxidant and anti-inflammatory effects, protection against lipid peroxidation (Bagchi, et. al., 1998) and last but not least, inhibition of cell death caused by glutamate via paralysis of calcium signals and creation of nitric oxide in neurons (Ahn, et. al., 2011). Therefore, when it comes to flavonoids, more specifically proanthocyanidin, studies only advance as new, somewhat promising discoveries are catalogued in various researches. One of these, for example, concerned new extraction and identification and separation processes for these compounds, taking a flavonoid-rich cell culture with Vaccinium Pahalae Skottsberg as the donor (Kandil, et. al., 2000). Therefore, the study was quite promising, as there was an absence of interfering compounds that could hinder the separation process, thus leading to the simple fractionation and purification of proanthocyanidins and the other phenolic compounds using vacuum chromatography. Antioxidant capacity measurements were also demonstrated from this research, generating high values and representing broad free radical fighting behavior as well as tumor formation inhibition in vitro.

Finally, a last study on proanthianidins, Figure 10, was analyzed, being consistent with a new proposal of flavonoid biosynthesis in cotton fibers (Xiao, et. al., 2014), always taking into account the benefits generated by the consumption of this class of natural dyes. A certain procedure was carried out using brown cotton fiber, since this is the most used raw material in the colored cotton industry, showing that the mass spectrometric analyses, by liquid chromatography, elucidated many of the compositions, such as the 2,3-trans form of the flavan-3-ols present in cotton fibers. The final result obtained was that the parameters detailed a fully activated proanthocyanidide biosynthesis pathway in brown cotton fiber, thus bringing yet another prospect of obtaining these specific compounds, thus increasing the necessary importance of the class of natural organic flavonoid dyes and their subclass, PA-proanthocyanidins.

Figure 10 - Proanthocyanidins structure.

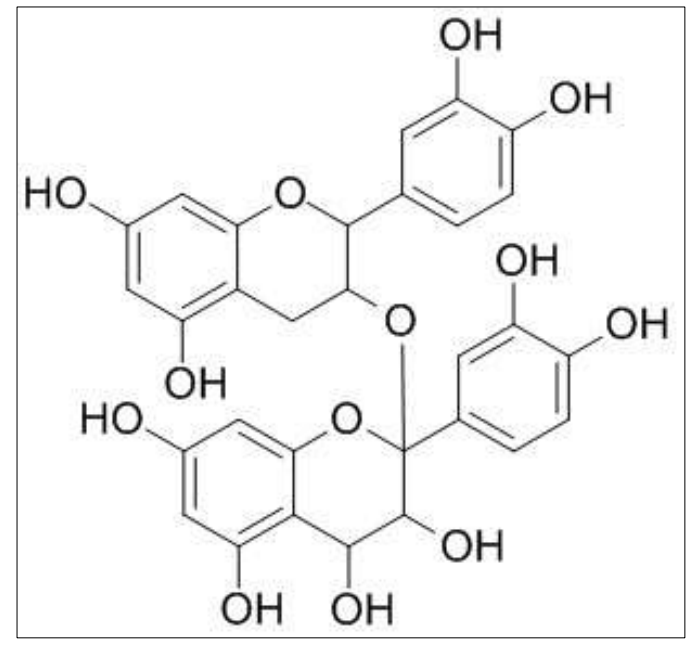

Source: Xiao, et. al. (2014).

\section{Conclusion}

In short, the proof that azocolor, artificial, caramel, synthetic, triphenylmethane and xanthene dyes can be easily replaced by natural organic dyes, with theoretical basis in the tables listed above, was addressed in a concise and consistent manner in this work. Therefore, once the damage caused by the dyes, set against the benefits proposed by the natural pigments were investigated as a solid basis in research previously conducted, and based on the resolution of the problem found today in the food, pharmaceutical and textile industries. This work brought with it a wide range of content and data diligently found. To achieve, thus, a greater effectiveness on what was discussed here, it is interesting that the consumer, once informed about certain 
issues, knows how to identify, according to the product packaging, the ingredients used in the manufacture of the product, because only in this way the compounds harmful to human health can be replaced by new sources of additives. With regard to clothes, or medicines, this procedure must be carried out. A fact to be considered is that the scientific community is already aware of all these issues, leading to the growth of the use of natural dyes, or pigments, in place of dyes such as tartrazine or amaranth, which are additives widely used today. It is also necessary to emphasize that, when dealing with compounds with carcinogenic potential or that corroborate oxidative stress, the techniques for their removal are very important, because, by means of these, the commercialized products will be free of such additives. Likewise, the methodologies for the identification of these dyes are of utmost importance, and this is due to the main reason that the rapid differentiation of such products makes their replacement faster and more effective. Thus, this work will contribute to studies in different areas in the future.

\section{References}

Abel, A. (2012). The history of dyes and pigments. Colour Design, 557-587. https://doi.org/10.1016/B978-0-08-101270-3.00024-2.

Abramsson-Zetterberg, L., \& Ilbäck, N. G. (2013). The synthetic food colouring agent Allura Red AC (E129) is not genotoxic in a flow cytometry-based micronucleus assay in vivo. Food and Chemical Toxicology, 59, 86-89. https://doi.org/10.1016/j.fct.2013.05.047.

Ahn, S. H.. Kim, H. J., Jeong, I., Hong, Y. J., Kim, M. J., Rhie, D. J., Jo, Y. H., Hahn, S. J. \& Yoon, S. H. (2011) Grape seed proanthocyanidin extract inhibits glutamate-induced cell death through inhibition of calcium signals and nitric oxide formation in cultured rat hippocampal neurons. BMC Neuroscience, 12(78), 1-12. https://doi: 10.1186/1471-2202-12-78.

Al-Degs, Y. S., Halawa, R. A. E. \& Alrub, S. S. A. (2012). Analyzing adsorption data of erythrosine dye using principal component analysis. Chemical Engineering Journal, 191, 185-194. https://doi.org/10.1016/j.cej.2012.03.002.

Ali, M. A. \& Bashier, S. A. (2006). Effect of fast green dye on some biophysical properties of thymocytes and splenocytes of albino mice. Food Additives and Contaminants, 23(5), 452-461. https://doi.org/10.1080/02652030500522598.

Bagchi, D., Garg, A., Krohn, R. L., Bagchi, M., Bagchi, D. J., Balmoori, J. \& Stohs, S. J. (1998). Protective Effects of Grape Seed Proanthocyanidins and Selected Antioxidants against TPA-Induced Hepatic and Brain Lipid Peroxidation and DNA Fragmentation, and Peritoneal Macrophage Activation in Mice. General Pharmacology: The Vascular System 30(5), 771-776. https://doi.org/10.1016/S0306-3623(97)00332-7.

Bahorun, T., Ramma, A. L., Crozier, A. \& Aruoma, O. I. (2004). Total phenol, flavonoid, proanthocyanidin and vitamin C levels and antioxidant activities of Mauritian vegetables. Journal of the Science of Food and Agriculture, 84, 12, 1553-1561. https://doi.org/10.1002/jsfa.1820.

Balta, I., Sevastre, B., Mireșan, V., Taulescu, M., Raducu, C, Longodor, A. L., Marchiș, Z., Mariș, C. S. \& Coroian, A. (2019). Protective effect of blackthorn fruits (Prunus spinosa) against tartrazine toxicity development in albino Wistar rats. BMC Chemistry, 13(104), 1-11, ago./2019.

https://doi.org/10.1186/s13065-019-0610-y.

Bașak, K., Bașak, P. Y., Doğuç, D. K., Aylak, F., Oğuztüzün, S., Bozer, B. M. \& Gültekin, F. (2016). Does maternal exposure to artificial food coloring additives increase oxidative stress in the skin of rats?. Human \& Experimental Toxicology, 36, 10, 1023-1030. https://doi.org/10.1177/0960327116678297.

Başak, K., Doguç, D. K., Aylak, F., Karadayi, N. \& Gültekin, F. (2014). Effects of Maternally Exposed Food Coloring Additives on Laryngeal Histology in Rats. Journal of Environmental Pathology, Toxicology and Oncology, 33(2), 123-130. https://doi.org/10.1615/JEnvironPatholToxicolOncol.2014008723.

Bettin, F., Cousseau, F., Martins, K., Zaccaria, S., Girardi, V., Silveira, M.M. \& Dillon, A.J.P. (2019). Effects of pH, Temperature and Agitation on the Decolourisation of Dyes by Laccase-Containing Enzyme Preparation from Pleurotus sajor-caju. Brazilian Archives of Biology and Technology, 62, e19180338. https://doi.org/10.1590/1678-4324-2019180338.

Beutner, S., Bloedorn, B., Frixel, S., Blanco, I. H., Hoffmann, T.,, Martin, H. D., Mayer, B., Noack, P., Ruck, C., Schmidt, M., Sch ̈̈lke, I., Sell, S., Ernst, H., Haremza, S., Seybold, G., Sies, H., Stahl, W. \& Walsh, R. (2001). Quantitative assessment of antioxidant properties of natural colorants and phytochemicals: carotenoids, flavonoids, phenols and indigoids. The role of $\beta$-carotene in antioxidant functions. Journal of the Science of Food and Agriculture, 81(6), 559568. https://doi.org/10.1002/jsfa.849.

Bueno, J.M., Sáez-Plaza, P., Escudero, F.R., Jiménez, A.M., Fett, R. \& Asuero, A.G. (2012). Analysis and Antioxidant Capacity of Anthocyanin Pigments. Critical Reviews in Analytical Chemistry, 42,126-151. https://doi.org/10.1080/10408347.2011.632314.

Cho, J. S., Nguyen, V. P., Jeon, H. W., Kim, M. H., Eom, S. H., Lim, Y. J., Kim, W. C., Park, E. J., Choi, Y. I. \& Ko, J. H. (2016). Overexpression of PtrMYB119, a R2R3-MYB transcription factor from Populus trichocarpa, promotes anthocyanin production in hybrid poplar. Tree Physiology, 36(9), 1162-1176. https://doi.org/10.1093/treephys/tpw046.

Dangles, O., Goupy, P., Carail, M., Giuliani, A., Duflot, D. \& Veyrat, C. C. (2018). Carotenoids: Experimental Ionization Energies and Capacity at Inhibiting Lipid Peroxidation in a Chemical Model of Dietary Oxidative Stress. The Journal of Physical Chemistry B, 122(22), 5860-5869. https://doi.org/10.1021/acs.jpcb.8b03447.

Degs, Y. S. A., Halawa, R. A. E. \& Alrub, S. S. A. (2012). Analyzing adsorption data of erythrosine dye using principal component analysis. Chemical Engineering Journal, 191, 185-194. https://doi.org/10.1016/j.cej.2012.03.002. 
Doguc, D. K., Ceyhan, B. M., Ozturk, M. \& Gultekin, F. (2012). Effects of maternally exposed colouring food additives on cognitive performance in rats. Toxicology and Industrial Health, 29(7), 616-623. https://doi.org/10.1177/0748233712436638.

Dotto, G. L., Pinto, L. A. A., Hachicha, M. A. \& Knani, S. (2015). New physicochemical interpretations for the adsorption of food dyes on chitosan films using statistical physics treatment. Food Chemistry, 171, 1-7. https://doi.org/10.1016/j.foodchem.2014.08.098.

Dwivedi, K. \& Kumar, G. (2015). Genetic Damage Induced by a Food Coloring Dye (Sunset Yellow) on Meristematic Cells of Brassica campestris L.: Journal of Environmental and Public Health. Hindawi Publishing Corporation, 2015(319727), 1-5. https://doi.org/10.1155/2015/319727.

El-Nabarawy, S. K., Radwan, O. K., Sisi, S. F. E. \& Razek, A. M. A. (2015). Comparative Study of Some Natural and Artificial Food Coloring Agents on Depression, Anxiety and Anti-Social Behavior in Weanling Rats. Journal of Pharmacy and Biological Sciences, 10(2), 83-89. https://doi.org/10.9790/300810238389 .

Elsevier. (2021). Atividades Biológicas dos Pigmentos Naturais e Malefícios dos Corantes Alimentícios.

El-Sisi, S. F., Radwan, O. K., El-Nabarawy, S. K. \& Abdel-Razek, A. M. (2015). Comparative Study of Some Natural and Artificial Food Coloring Agents on Hyperactivity, Learning and Memory Performance in Weanling Rats. International Journal of Sciences: Basic and Applied Research (IJSBAR), 21(2), 309-324. https://www.gssrr.org/index.php/JournalOfBasicAndApplied/article/view/3827/2239.

Espinosa-Acosta, G., Jacques, A. L. R., Molina, G. A., Cornejo, J. M., Esparza, R., Martinez, A. R. H., González, I. S. \& Estevez, M. (2018). Stability Analysis of Anthocyanins Using Alcoholic Extracts from Black Carrot (Daucus Carota ssp. Sativus Var. Atrorubens Alef.). Molecules, 23(11), 1-16. https://doi.org/10.3390/molecules23112744.

Gerardi, C., Tommasi, N., Albano, C., Blando, F., Rescio, L., Pinthus, E. \& Mita, G. (2015). Prunus mahaleb L. fruit extracts: a novel source for natural food pigments. European Food Research and Technology, 241, 683-695. https://doi.org/10.1007/s00217-015-2495-x.

Goldenring, J. R., Woo, R. S., Shaywitz B. A., Batter D. K., Cohe D. J., Young J. G. \& Teicher M. H. (1980). Effects Of Continuous Gastric Infusion Of Food Dyes On Developing Rat Pups. Life Sciences, 27(20), 1897-1904. https://www.talkingaboutthescience.com/studies/Goldenring1980.pdf

Gross, B. L., Reagon, M., Hsu, S. C., Caicedo, A. L., Jia, Y. \& Olsen, K. M. (2010). Seeing red: the origin of grain pigmentation in US weedy rice. Molecular Ecology, 19(16), 3380-3393. https://doi.org/10.1111/j.1365-294X.2010.04707.x.

Gupta, V. K., Mittal, A., Kurup, L. \& Mittal, J. (2006). Adsorption of a hazardous dye, erythrosine, over hen feathers. Journal of Colloid and Interface Science, 304(1), 52-57. https://doi.org/10.1016/j.jcis.2006.08.032.

Hamdi, M., Nasri, R., Dridi, N., Li, S. \& Nasri, M. (2020). Development of novel high-selective extraction approach of carotenoproteins from blue crab (Portunus segnis) shells, contribution to the qualitative analysis of bioactive compounds by HR-ESI-MS. Food Chemistry, 302, 1-10. https://doi.org/10.1016/j.foodchem.2019.125334.

Jaworska, M., Szulińska, Z., Wilk, M. \& Anuszewska, E. (2005). Separation of synthetic food colourants in the mixed micellar system Application to pharmaceutical analysis. Journal of Chromatography A, 1081(1), 42-47. https://doi.org/10.1016/j.chroma.2005.03.045.

Kandil, F. E., Song, L., Pezzuto, J. M., Marley, K., Seigler, D. S. \& Smith, M. A. L. (2000). Isolation of Oligomeric Proanthocyanidins from Flavonoid-Producing Cell Cultures. In Vitro Cellular \& Developmental Biology - Plant, 36, 492-500. https://doi.org/ 10.2307/4293395.

Kuskoski, E. M.; Asuero, A. G.; Parilla, M. C. G.; Troncoso, A. M. \& Fett, R. (2004). Actividad Antioxidante De Pigmentos Antociánicos. Food Science and Technology, 24(4), 691-693. https://doi.org/10.1590/S0101-20612004000400036.

Liberati, A., Altman, D. G., Tetzlaff, J., Mulrow, C., Gøtzsche, P.C., Ioannidis, J. P. A., Clarke, M., Devereaux, P. J., Kleijnen, J. \& Moher, D. (2009). The PRISMA statement for reporting systematic reviews and meta-analyses of studies that evaluate health care interventions: Explanation and elaboration. Italian Journal of Public Health. 6(4), 354-391. https://doi.org/10.1136/bmj.b2700.

Liberato, M. C. T. C. (2020). Química dos Alimentos: Estruturas, Propriedades e Transformações. 1. ed. Belo Horizonte: Poisson, 1-88. https://doi.org/10.36229/978-65-5866-003-3.

Lin, W. S., He, P. H., Chau, C. F., Liou, B. K., Li, S. \& Pan, M. H. (2018). The feasibility study of natural pigments as food colorants and seasonings pigments safety on dried tofu coloring. Food Science and Human Wellness, 7(3), 220-228. https://doi.org/10.1016/j.fshw.2018.09.002.

Maekawa, A., Ogiu, T., Matsuok, C., Onodera, H., Furuta, K., Tanigawa, H., Hayash, Y. \& Odashima, S. (1983) Carcinogenicity Study of Ammonia-Process Caramel In F344 Rats. Food and Chemical Toxicology, 21(3), 237-244. https://doi.org/10.1016/0278-6915(83)90054-6.

Maia, M., Resende, D. I. S. P., Duraes, F., Pinto, M. M. M. \& Sousa, E. (2021). Xanthenes in Medicinal Chemistry e Synthetic strategies and biological activities. European Journal of Medicinal Chemistry, 210, 113085. https://doi.org/10.1016/j.ejmech.2020.113085.

Medeiros, R. A., Lourencao, B. C., Filho, R. C. R. \& Filho, O. F. (2012). Simultaneous voltammetric determination of synthetic colorants in food using a cathodically pretreated boron-doped diamond electrode. Talanta, 97, 291-297. https://doi.org/10.1016/j.talanta.2012.04.033.

Moher, D., Liberati, A., Tetzlaff, J., Altman, D. G. \& PRISMA Group (2009). Reprint--preferred reporting items for systematic reviews and meta-analyses:the PRISMA statement. Phys Ther, 89, 873-80. https://doi.org/10.1016/j.jclinepi.2009.06.005.

Mourtzinos, I., Prodromidis, P., Grigorakis, S., Makris, D. P., Biliaderis, C. G. \& Moschakis, T. (1983). Natural food colourants derived from onion wastes: application in a yoghurt product. Electrophoresis, 39(15), 1975-1983. https://doi.org/10.1002/elps.201800073

Mutsuga, M., Sato, K., Hirahara, Y. \& Kawamura, Y. (2011). Analytical methods for $\mathrm{SiO}_{2}$ and other inorganic oxides in titanium dioxide or certain silicates for food additive specifications. Food Additives and Contaminants: Part A, 28(4), 423-427. https://doi.org/10.1080/19440049.2010.551548. 
Ohtoyo, M., Machinaga, N., Inoue, R., Hagihara, K., Yuita, H., Tamura, M., Hashimoto, R., Chiba, J., Muro, F., Watanabe, J., Kobayashi, Y., Abe, K.. Kita, Y., Nagasaki, M. \& Shimozato, T. (2016). Component of Caramel Food Coloring, THI, Causes Lymphopenia Indirectly via a Key Metabolic Intermediate. Cell Chemical Biology, 23(5), 555-560. https://doi.org/10.1016/j.bbrc.2013.03.004.

Orona-Navar, A., Hernández, I. A., Luke, T. L., Zarazúa, I., Arellano, V. R., Guerrero, J. P. \& Soto, N. O. (2020). Photoconversion efficiency of Titania solar cells co-sensitized with natural pigments from cochineal, papaya peel and microalga Scenedesmus obliquus. Journal of Photochemistry \& Photobiology, A: Chemistry, 388(1), 1-48. https://doi.org/10.1016/j.jphotochem.2019.112216.

Page, M.J., Mckenzie, J.E., Bossuyt, P.M., Boutron, I., Hoffmann, T.C., Mulrow, C.D., Shamseer, L., Tetzlaff, J.M., Akl, E.A., Brennan, S.E., Chou, R., Glanville, J., Grimshaw, J.M., Hróbjartsson, A., Lalu, M.M., Li, T., Loder, E.W., Wilson, E.M., Mcdonald, S., Mcguinness, L.A., Stewart, L.A., Thomas, J., Tricco, A.C., Welch, V.A., Whiting, P. \& Moher, D. (2021). The PRISMA 2020 statement: an updated guideline for reporting systematic reviews. PLOS Medicine 18(3), e1003583.

Paixão, R. M., Silva, L. H. B. R., Reck, I. M., Vieira, M. F., Bergamasco, R. \& Vieira, A. M. S. (2019). Deposition of graphene nanoparticles associated with tannic acid in microfiltration membrane for removal of food colouring. Environmental Technology, 40, 1-7. https://doi.org/10.1080/09593330.2019.1627426.

Panzella, L., Eidenberger, T. \& Napolitano, A. (2018). Anti-Amyloid Aggregation Activity of Black Sesame Pigment: Toward a Novel Alzheimer's Disease Preventive Agent. Molecules, 23(3), 1-13. https://doi.org/10.3390/molecules23030676.

Park, W. S., Kim, H. J., Li, M., Lim, D. H., Kim, J., Kwak, S. S., Kang, C. M., Ferruzzi, M. G. \& Ahn, M. J. (2018). Two Classes of Pigments, Carotenoids and C-Phycocyanin, in Spirulina Powder and Their Antioxidant Activities. Molecules, 23(8), 1-11. https://doi.org/10.3390/molecules23082065.

Periódicos Capes. (2021). Corantes e Pigmentos Naturais.

Phommalath, S., Teraishi, M., Yoshikawa, T., Saito, H., Tsukiyama, T., Nakazaki, T., Tanisaka, T. \& Okumoto, Y. (2014). Wide genetic variation in phenolic compound content of seed coats among black soybean cultivars. Breeding Science, 64(4), 409-415. https://doi.org/10.1270/jsbbs.64.409.

Richhariya, G. \& Kumar, A. (2018). Fabrication and characterization of mixed dye: Natural and synthetic organic dye. Optical Materials, 79(1), 296-301. https://doi.org/10.1016/j.optmat.2018.03.056.

Roychoudhury, A. \& Giri, A. K. (1989). Effects of certain food dyes on chromosomes of A llium cepa. Genetic Toxicology, 223(3), 313-319. https://doi.org/10.1016/0165-1218(89)90125-0.

Santana, G. M., Sousa, J. J. A. \& Peron, A. P. (2015). Action of Ponceau 4R (E-124) food dye on root meristematic cells of Allium cepa L. Acta Scientiarum, 37(1), 101-106. https://doi.org/10.4025/actascibiolsci.v37i1.23119.

Schweiggert, R.M. (2018). Perspective on the Ongoing Replacement of Artificial and Animal Based Dyes with Alternative Natural Pigments in Foods and Beverages. Journal of Agricultural and Food Chemistry, 66, 3074-3081. https://doi.org/10.1021/acs.jafc.7b05930.

Sisi, S. F. E., Radwan, O. K., Nabarawy, S. K. E. \& Razek, A. M. A. (2015). Comparative Study of Some Natural and Artificial Food Coloring Agents on Hyperactivity, Learning and Memory Performance in Weanling Rats. International Journal of Sciences: Basic and Applied Research, 21(2), $309-324$. https://doi.org/10.1111/j.1750-3841.2011.02267.x

Siwińska-Stefańska, K., Nowacka, M., Radzimska, A. K. \& Jesionowski, T. (2012). Preparation of hybrid pigments via adsorption of selected food dyes onto inorganic oxides based on anatase titanium dioxide. Dyes and Pigments, 94(2), 338-348. https://doi.org/10.1016/j.dyepig.2012.01.017.

Srivastava, J. \& Vankar, P. S. (2015). Carotenoids: as natural food colorant from Canna flowers. Pigment \& Resin Technology, 44(1), 13-18. https://doi.org/10.1108/PRT-12-2013-0112.

Stoll, L., Rech, R., Flôres, S. H., Nachtigall, S. M. B. \& Rios, A. O. (2018). Carotenoids extracts as natural colorants in poly(lactic acid) films. Journal of Applied Polymer Science, 135(33), 1-9. https://doi.org/10.1002/app.46585.

Taheri, A., Nasab, M. K. \& Movafeghi, A. (2015). Effects of Different Strengths of Medium on Production of Phenolic and Flavonoid Compounds in Regenerated Shoots of Ziziphora persica. Russian Agricultural Sciences, 41(4), 225-229. https://doi.org/10.21608/jpp.2017.37464.

Tripathy, S. \& Nair, P. V. (2012). Adverse drug reaction, patent blue V dye and anaesthesia. Indian Journal of Anaesthesia, 56(6), 563-566. https://doi.org/10.4103/0019-5049.104576.

Vidal, B. C. \& Mello, M. L. S. (2005). Supramolecular Order Following Binding of the Dichroic Birefringent Sulfonic Dye Ponceau SS to Collagen Fibers. Biopolymers, 78(3), 121-128. https://doi.org/10.1002/bip.20274.

Xiao, Y., Yan, Q., Ding, H., Luo, M., Hou, L., Zhang, M., Yao, D., Liu, H. S., Li, X., Zhao, J. \& Pei, Y. (2014). Transcriptome and Biochemical Analyses Revealed a Detailed Proanthocyanidin Biosynthesis Pathway in Brown Cotton Fiber. PLOS ONE, 9(1), 1-9. https://doi.org/10.1371/journal.pone.0086344.

Xu, H. X., Wan, M., Dong, H., But, P. P. H. \& Foo, L. Y. (2000). Inhibitory Activity of Flavonoids and Tannins against HIV-1 Protease. Biological and Pharmaceutical Bulletin, 23(9), 1072- 1076. https://doi.org/10.1248/bpb.23.1072.

Xu, J., Zhang, Y., Zhou, H., Wang, M., Xu, P. \& Zhang, J. (2012). An Amperometric Sensor for Sunset Yellow FCF Detection Based on Molecularly Imprinted Polypyrrole. Engineering, 5, 159-162. https://doi.org/10.4236/eng.2012.410B041.

Zetterberg, L. A. \& Ilbäck, N. G. (2013). The synthetic food colouring agent Allura Red AC (E129) is not genotoxic in a flow cytometry-based micronucleus assay in vivo. Food and Chemical Toxicology, 59, 86-89. https://doi.org/10.1016/j.fct.2013.05.047.

Zhang, G. \& Ma, Y. (2013). Mechanistic and conformational studies on the interaction of food dye amaranth with human serum albumin by multispectroscopic methods. Food Chemistry, Science Direct, 136(2), 442-449. https://doi.org/10.1016/j.foodchem.2012.09.026.

Zhang, J., Hou, X., Ahmad, H., Zhang, H.; Zhang, L. \& Wang, T. (2014). Assessment of free radicals scavenging activity of seven natural pigments and protective effects in AAPH-challenged chicken erythrocytes. Food Chemistry, 145(1), 57-65. https://doi.org/10.1016/j.foodchem.2013.08.025. 